\title{
(2) \\ An Overview of Capsiate in Management of Hypothermia and Life Style Diseases
}

\author{
Ankit Awasthi *, Rubiya Khursheed, Monica Gulati, Sachin Kumar Singh \\ School of Pharmaceutical Sciences, Lovely Professional University, Phagwara, Punjab-144411, India
}

Address for Correspondence: Ankit Awasthi

\section{Received: \\ 01.03.2019 \\ Accepted: \\ 25.03.2019 \\ Keywords \\ Capsicum \\ annuum; \\ Diabetes; \\ Obesity.}

\begin{abstract}
Capsiate is an important non-pungent phytoconstituent which is obtained from the fruits of plant Capsicum annuum. Due to non-pungency, capsiate is used in food items instead of capsaicin. The reason of capsiate non-pungency is due to its expeditious hydrolysation in the presence of aqueous conditions, which leads to decrease in its approachability towards nociceptors e.g., in the oral cavity. Capsiate consists of ester linkage between fatty acid chain and the vanillyl group while capsaicin consists of amide linkage between the vanillyl group and the fatty acid chain. On metabolism capsiate gets biotransformed and decomposed into vanillyl alchol, vanillic acid and glucuronide conjugates. Capsiate is a novel pharmacotherapeutic which helps in the management of various diseases like hypothermia, diabetes and obesity. Capsiate shows different mechanism of action in different diseases. In hypothermia capsiate act on vanilloid receptor subtype transient receptor potential cation channel subfamily V member 1 (TRPV1) and shows thermogenic effect. While in diabetes, capsiate increases the mass of beta cells which leads to increase in proliferation or decrease apoptosis of $\beta$ cells and further potentiates insulin/insulin like growth factor (IGF-1) signaling. In obesity, capsiate downregulates uncoupling protein 3 (UCP-3) and enhance muscle oxidative capacity and results in decrease of abdominal fat. Through the current presentation an attempt has been made to highlight various pharmacological actions of capsiate. () 2019 iGlobal Research and Publishing Foundation. All rights reserved.
\end{abstract}

Cite this article as: Awasthi, A.; Khursheed, R.; Gulati, M.; Singh, S.K. An overview of capsiate in management of hypothermia and life style diseases. Indo Global J. Pharm. Sci., 2019; 9(2Suppl.): 111. DOI: http://doi.org/10.35652/IGJPS.2019.92S09.

Indo Global Journal of Pharmaceutical Sciences( ISSN 2249 1023; CODEN- IGJPAI; NLM ID: 101610675) indexed and abstracted in CrossRef (DOI Enabling), UGC CARE Journal List, EMBASE(Elsevier), National Library of Medicine (NLM) Catalog, ResearchGate, Publons, CAS (ACS), Index Copernicus, Google Scholar and many more. For further details, visit http://iglobaljournal.com

This is a special issue as an outcome of 'RAPSCON-2019' sponsored by APTI and organized by Sri Sai College of Pharmacy, Manawala, Amritsar, Punjab, India. Relaxation offered in journal format. 